\title{
Preparation to Prevent, Detect, and Manage Fraud: A Study of Not-for-Profits in South Central Pennsylvania
}

\author{
Gabrielle P. Fish \\ Liberty University
}

\author{
Stanley W. Self \\ Purdue University Global \\ Gevorg Sargsyan \\ Lamar University \\ Tonjua McCullough \\ Purdue University Global
}

Fraud is an expanding problem in not-for-profit organizations; the lack of fraud-prevention preparation by NFP financial professionals contributes to the problem. A gap in existing research yields limited data regarding fraud prevention training and preparation of NFP professionals. This study examines existing research regarding fraud, and techniques used to train and prepare professionals to prevent, detect, and manage fraud. A qualitative exploratory case study design is used; fifteen participants achieved data saturation. The data revealed one major theme and four minor themes. Those themes indicate a need for additional fraud research in NFPs. Suggestions for further preparation for NFP professionals are offered.

Keywords: not-for-profit, fraud, segregation of duties, fraud-prevention training

\section{INTRODUCTION}

Fraud is a significant problem in all industries resulting in a reduction of gross revenues annually (Kummer, et al., 2015). Not-for-Profit (NFP) organizations are especially susceptible to fraudulent activity due to underdeveloped governance practices, an environment of trust, and a lack of internal controls. After the Enron and WorldCom scandals, accounting professionals seek more in-depth forensic accounting education to better prepare for their profession (Kramer, et al., 2017). The harm that fraud causes to NFP entities suggest that improving fraud prevention, detection, and management preparation could significantly reduce losses.

This study was designed to fill existing gaps in the literature by answering the following research question: What preparations have NFP accountants had that would equip them for fraud prevention, identification, and management, if any? 
An exploratory, qualitative multi-case study was conducted to answer the question. In this study, the researchers aimed to determine what forms of fraud-training and preparation NFP financial professionals had received prior to experiencing asset misappropriation fraud in the workplace. Additionally, answering this research question enabled the identification of underutilized tools and techniques that would benefit NFP financial professionals in fraud-training and preparation.

\section{LITERATURE REVIEW}

The following section examines existing research related to this study. Specifically, it addresses tools and techniques that financial professionals use or have available to them to combat workplace-fraud.

\section{Tools and Techniques Available to Combat Fraud}

A variety of techniques can help NFP organizations lower fraud risk. Paneth's 2014 leadership survey indicated only $20 \%$ of NFP leaders have a risk assessment process in place, and $43 \%$ believe the cost of facilitating such processes is a major challenge (McNee, 2015). Risk assessment and the implementation of internal controls help prevent and detect fraud quicker. Some forms of fraud detection, prevention, and management can be costly; however, there are effective tools to lower risk.

\section{Risk Assessment}

Risk assessment reviews the changes in the environment that impede a business from meeting its objectives (Trompeter, et al., 2013). Assessing risk is an auditing requirement; Statement on Auditing Standards (SAS) No. 99 requires auditors to determine weaknesses enabling fraud to occur at each client. Organizations conducting a risk assessment should identify a plan for detecting fraud, estimate the significance and likelihood of fraud, and determine actions to manage it (Al-Thuneibat, et al., 2015). Because business conditions change constantly, risk assessment is necessary to detect threats (Kong, et al., 2018). Research suggests that assessing risk and implementing risk management reduces the unpredictability of financial performance (Al-Thuneibat, et al., 2015).

Bik and Hooghiemstra (2018) indicated that fraud risk assessment relies on professional judgment. Judgment is not enough to prevent fraud; supplementing internal controls is vital (Kong, et al., 2018). Internal controls are used to minimize existing risks (Mohd-Nassir, et al., 2016). Internal auditors can perform risk assessments, but bias could exist based on their relation to management (Wang \& Fargher, 2015). Hiring an auditing firm to perform an assessment can reveal weaknesses that internal auditors might overlook.

\section{Control Environment}

The control environment is the basis for internal control design (Rubino, et al., 2017). According to Noland and Metrejean (2013), the control environment reflects top management's attitudes based on actions and policies. The Committee of Sponsoring Organizations of the Treadway Commission (COSO) framework lists the control environment as the first, and most important, component for evaluating internal controls (Trompeter, et al., 2013). It includes elements such as integrity, ethics, management's attitude (also termed "tone at the top"), organizational structure, a delegation of authority, management philosophy, and professionalism of employees.

According to Sow, et al. (2018), management's interaction with internal controls determines their ability to prevent fraud. Kong, et al. (2018) believe the control environment is the organization's foundation for forming all control elements and reflects the corporate culture. The control environment should make evident the ethical commitment of the company to help management make strategic decisions and manage risk. This factor directly affects the mindset of employees and the strength of internal controls (Le \& Tran, 2018). If the control environment is strong, then employee morale is improved and risks for asset misappropriation decrease. Le and Tran also indicated that the control environment was the strongest opposition to fraud. Although a strong control environment is important, it needs support from strict internal controls to prevent and detect fraud. 


\section{Internal Controls}

Internal controls are processes enacted by management and the board of directors to reasonably assure the achievement of goals, reporting, and compliance (Suh, et al., 2019). Controls set a standard for how to present data. They mitigate risk but do not detect fraud (Burchett, 2017). Detection occurs when someone notices a deviation from standards. Although well-designed internal controls cannot eliminate all fraud, they deter fraudsters by reducing fraud opportunities. According to the Association of Certified Fraud Examiners (ACFE) (2018), internal control weakness is the cause for only half of the fraud. This report reveals that auditing internal controls reduced fraud duration and loss by $50 \%$. Asset misappropriation fraud occurred most when there was a lack of internal controls. Examples of internal controls are segregation of duties, task rotation, whistleblower policies, effective audit teams, and vacation policies (Hollow, 2014; Kong, et al., 2018)

\section{Preparation of Accountants}

According to Self, et al. (2014), academic preparation and certification will have an impact on the effectiveness of a professional accountant. They further identify demographic aspects of the accounting profession that may impact the ability of organizations to identify fraud. An effective preparation may help NFP and other organizations to be able to better evaluate circumstances related to fraud (Self, et al., 2016; Self, et al., 2013).

\section{Audit Teams}

Effective audit teams are vital for internal control development and fraud detection and prevention (Chang, et al., 2019). The ACFE (2018) indicates that internal audit teams discover approximately 15 percent of fraud and external audit teams discover approximately four percent. Being an active detection method, internal audits are likelier to uncover fraud. The responsibilities of internal auditors are to "examine, evaluate, and monitor the adequacy and effectiveness of internal control" (Chang, et al., 2019, p. 1). Research verifies that the size of internal control audit teams, number of certifications, work experience, and levels of education affect internal controls and the number of deficiencies reported. NFPs experience restraints for internal audit teams because of smaller, less qualified workforces (Vitan \& Mihălţan, 2015). A study by Domanski (2016) of 235 Polish NFPs discovered that $75.7 \%$ have an internal audit procedure, and $64.3 \%$ think it is effective in preventing and detecting fraud. Implementing internal audit procedures in NFPs in the U.S. could lower fraud risk.

\section{Segregation of Duties}

Segregation of duties is the separation of business tasks (Singh \& Best, 2016). An organization that violates the principle of segregation of duties enables a fraudster to perpetrate and cover the crime. Research suggests that asset misappropriation fraud targets organizations with weak segregation of duties (Akkeren \& Buckby, 2017).

An organization's size can limit the ability to implement effective segregation of duties (Maguire, 2014). Small and medium-sized NFPs often lack the number of employees needed to segregate duties adequately (McSwain, et al., 2015). Because segregation of duties is a preventative internal control, the implementation should occur if job duties can create improper behavior or collusion making fraud likely (Liu, et al., 2014). To overcome insufficient staffing, Maguire (2014) suggests requesting the help of board members to perform tasks such as reconciliations or receiving the bank statement to properly segregate duties.

\section{Task Rotation}

Task rotation, or job rotation, is the cross-training of employees on various tasks and sporadic rotation of responsibilities (Jones, 2014). Job rotation is a lateral change never altering employee salary or hierarchical levels (Kampkötter, et al., 2016). Rotation is a prevention and detection method (Mirinaviciene, 2014). Fraud risk increases when employees stay in a position for an extended length of time; when 
employees change tasks, they provide a new perspective and can likely detect issues previously overlooked (Jones, 2014).

Employees build close relationships with customers and vendors, which creates fraud opportunities (Prabowo, 2014). Employee rotation lowers theft possibilities by changing the employees' duties and access to cash (Maguire, 2017). Alternating employees' jobs prevents manipulation of system weaknesses and concealment of fraud (Nawawi \& Salin, 2018a). Small organizations with limited employees, such as NFPs, struggle to implement task/job rotation (Andon, et al., 2015). Finding ways to do so can reduce fraud by approximately 23 percent (ACFE, 2018). According to the ACFE, less than 20 percent of companies with under 100 employees utilize task rotation. Research indicates that task rotation can save approximately $\$ 30,000$ annually, which is significant for NFPs with limited funds.

\section{Whistleblower Policies}

Whistleblowing is the disclosure of illegal, immoral, or unethical acts by members of an organization to individuals who can affect change (Scheetz \& Wilson, 2019). According to the ACFE, whistleblowing is the most effective form of fraud detection, with tips revealing approximately $40 \%$ of fraud (ACFE, 2018; Gao, et al., 2015). NFP studies indicate that organizations retaliate against whistleblowers (McDonnell \& Rutherford, 2018). A study conducted in the NFP sector by Rothschild (2013) discovered that internal whistleblowers endured retaliation including loss of a job or forced retirement, negative performance evaluations, being monitoring more closely, blacklisted from receiving other jobs in their field, and criticism and avoidance by co-workers. If the whistleblower used external means of reporting, then retaliation increased $10-15 \%$. Because of retaliation employees are disinclined to report fraud if known consequences exist. The ACFE recommends implementing anonymous hotlines to encourage employees to blow the whistle (Johansson \& Carey, 2016). Research suggests anonymity encourages fraud reporting because perceived personal cost decreases.

Psychological research theorizes that type of fraud affects whistleblower reporting (Scheetz \& Wilson, 2019). Social psychology explains that theft causes a personal gain leading the whistleblower to attribute more responsibility to the fraudster. Financial statement fraud benefits the organization leading the whistleblower to evaluate contextual factors, which often leads to lower reporting because they attribute less responsibility to the fraudster. This theory is consistent with conclusions from prior literature that whistleblowers are likelier to report asset misappropriation than financial statement fraud (Scheetz \& Wilson, 2019). McDonnell and Rutherford (2018) state that whistleblowers in NFPs observe misconduct multiple times before reporting. The threat of retaliation decreases the speed at which whistleblowing occurs. However, NFPs with a whistleblower policy is 2.093 times likelier to detect fraud than those without (Kummer, et al., 2015). Despite the benefits, only 11.5 percent of NFPs utilize whistleblower policies. Implementing such policies would reduce and asset misappropriation in NFPs faster.

\section{Vacation Policies}

Embezzlers may not take vacations because maintaining fraud requires constant attention; taking time away from the job may expose the fraudster (Reurink, 2018; Kramer, 2015). Vacation policies cannot prevent fraud alone; if the responsibilities are not reassigned when the employee is absent, the fraud might continue undetected (Maguire, 2017). Time off disrupts the fraudsters' routine and the substitute staff often discover the fraud (Prins \& Bhuse, 2018). According to the ACFE (2018), implementing mandatory vacation policies reduces fraud by approximately 23 percent. Only 19 percent of the 2,690 cases reviewed had a vacation policy in place; those without vacation controls suffered an average loss of $\$ 30,000$ more annually (ACFE, 2018). The Federal Deposit Insurance Corporation (FDIC) recommends forced vacation policies for banks that are effective in all sectors of business (Prins \& Bhuse, 2018).

\section{RESEARCH METHODOLOGY}

A qualitative research method was used for this study. The goal of this project was to develop a conclusion based on experiences (Azzaro, 2018). Researchers found this method as the most appropriate 
for collecting, reviewing, and analyzing the experiences of accountants who had fraud-prevention training within an NFP in South Central Pennsylvania. The research revealed a lack of literature related to fraudprevention training within the NFP sector; this study filled those gaps (Harris, et al., 2017).

Furthermore, this project was designed as a multiple case study allowing to gather experiences of various accountants for comparison and analysis. Each NFP considered a case; the researchers compared and contrasted each case for themes using a within-case and across-case analysis technique (Di Mauro, et al., 2018).

\section{Discussion of Method}

This project used qualitative research methods. Qualitative research explores the meanings attributed to the phenomenon by participants (Creswell, 2014). This method analyzes the experiences of participants to form conclusions (Daher, et al., 2017). In this study, researchers reviewed the fraud-prevention training of NFP accountants to conclude how well NFP professionals in South Central Pennsylvania were being prepared to prevent, detect, and manage fraud effectively. Because of the effects of fraud on NFP organizations, using qualitative methods was appropriate to gather the perceived qualitative data related to preparedness to prevent, detect, and manage fraud. Also, this method helped to collect opinions about improving the preparation of such occurrences in the workplace.

Prior research indicates that qualitative methods are useful to gather the perceptions and experiences of fraud from participants (Akkeren \& Buckby, 2017). The qualitative method enabled the researcher to use interpersonal skills throughout the process (Sahloul, et al., 2019). After data was gathered, the researchers reviewed the information for themes by identifying commonalities and differences. By considering participant opinions and perceptions, the principal investigator developed an understanding of the lived experiences of the NFP accountants and how to improve their preparation for preventing, detecting, and managing fraud.

\section{Discussion of Design}

The case study design allows analysis of phenomenon from different perspectives by examining multiple insights (Sahloul, et al., 2019; Yin, 2009). This research design enabled to gather various experiences of preparedness of NFP financial professionals for preventing, detecting, and managing fraud. Multiple case studies helped to identify the most beneficial tools and techniques for NFPs to lower the fraud risk and better prepare their accountants. NFP organizations outside of South-Central Pennsylvania can use the conclusions to identify improvements and techniques that would be useful for their needs.

There are different types of multiple case studies: exploratory, descriptive, and explanatory (Scholz \& Tietje, 2002). This study followed the exploratory design. Exploratory case studies are similar to pilot studies because they examine a phenomenon not widely addressed in existing research and then develop new hypotheses (Fahy, 2013; Hollow, 2014; Scholz \& Tietje, 2002). Because fraud in NFPs is not widely studied and there is a lack of literature regarding it (Harris et al., 2017). This research design helped to gather experiences and opinions from participants, analyzed the data, and developed theories that would further the knowledge of fraud-prevention training in the NFP sector.

\section{RESULTS}

\section{Major Theme}

The major theme that emerged answered the research question: "What preparations have NFP accountants had that would equip them for fraud prevention, identification, and management if any?" The major theme was: "Various forms of fraud-prevention training will better prepare staff for preventing, detecting, and managing fraud." Table 1 indicates the types of fraud preparation that participants had.

Although most of the participants had received more than one form of fraud-prevention training, two stated they had received no fraud prevention, detection, and management training. This theme supported the problem that NFP accounting and finance staff need improved fraud prevention, detection, and management training. 
TABLE 1

TYPES OF FRAUD PREPARATION RECEIVED BY PARTICIPANTS

\begin{tabular}{|l|l|}
\hline Type of preparation & Number of participants who received it \\
\hline Continuing professional education (CPE) & 11 \\
\hline Collegiate auditing course & 10 \\
\hline Training from prior organizations & 5 \\
\hline Reading articles in the journal of accountancy & 1 \\
\hline Collegiate business ethics course & 1 \\
\hline AICPA/CFE fraud course & 2 \\
\hline External conferences/presentations & 2 \\
\hline Training at the organization & 3 \\
\hline No training received & 2 \\
\hline
\end{tabular}

Furthermore, the researchers asked questions regarding what types of topics have been beneficial to learn over the course of their careers. Table 2 identifies topics as vital to proper fraud prevention, detection, and management.

TABLE 2

FRAUD PREPARATION TOPICS

\begin{tabular}{|l|}
\hline $\begin{array}{l}\text { Topics that participants indicated were beneficial to effective fraud prevention, detection, and } \\
\text { management preparation }\end{array}$ \\
\hline Professional skepticism \\
\hline Case studies \\
\hline Real-life experience \\
\hline Auditing courses \\
\hline Attitude of employees \\
\hline Cybercrime \\
\hline Tone at the top \\
\hline Supervisor oversight \\
\hline
\end{tabular}

Eleven participants (73\%) indicated the importance of learning and implementing professional skepticism. Participant AQ works for a religious organization and mentioned, "Even people who are Christians do not mean that they're not tempted to commit fraud." Similarly, participant IY explained that although many of the employees are Christians, "that does not always mean something of value. Christians might still commit fraud." Furthermore, participant CN believed that "lack of healthy skepticism creates an environment in which fraud or misappropriation would be otherwise more likely to occur." Participant CN went on further to state that "a healthy skepticism would go a long way." Participant SE stated that "You have to take the time... you can look at somebody and think they're the most trustworthy person ever." However, that does not mean you should not review their work and complete proper audit checks to ensure accuracy and honesty. Participant JF summarized the need for professional skepticism well stating that "Every organization has to take seriously the fact that anybody can be that next perpetrator." In reviewing the transcriptions, professional skepticism was the topic that came up the most regarding proper fraud prevention, detection, and management preparation.

Other topics that participants indicated as relevant include learning from case studies and real-life experience and putting the lessons from them into practice. One participant indicated that interns review specific cases of fraud and discuss them. The participant believes that people leaving college and entering the workforce do not have a healthy professional skepticism; showing them real-life examples of fraud helps them understand what can take place in an organization. Other participants believed that the best 
experience, unfortunately, came from having identified and managed fraud themselves. Using experiences and examples proven by multiple NFPs can be beneficial and help professionals understand the risks and weaknesses in organizations similar to theirs. Understanding the mistakes of other organizations can benefit NFPs by enabling them to improve weaknesses they overlooked.

The various topics addressed by participants proves the importance of utilizing different training techniques to improve the ability of accountants to prevent, detect, and manage fraud. Seeking out different forms of education and training will help accountants learn about more topics and better prepare themselves in the long run. Within this theme, there were four minor themes that emerged.

\section{Minor Theme 1}

The first minor theme identified was: "adequate fraud prevention and detection training is important." Nine participants (60\%) mentioned the importance of adequate fraud-prevention training. Participant PX stated that "more training is always good." Additionally, participant KT noted that they are, "always looking for good education and... fraud detection is always important for us."

Conversely, participant GK revealed that they had no fraud-prevention training. Participant GK stated that "training of staff could be better" and that the organization does not have a standard regarding fraudprevention training. Participant GK stated that further training would be necessary for the staff to manage fraud adequately. This minor theme indicates the need for adequate fraud-prevention training for individuals in accounting and finance roles. Although many participants felt prepared to manage fraud if it were to occur, some felt that they were unprepared due to a lack of training and education. By informing individuals of available training and education, their ability and confidence regarding fraud prevention, detection, and management will enable them to lower their organization's risk.

\section{Minor Theme 2}

The second minor theme that emerged was CPE courses and webinars are beneficial training tools. From a convenience standpoint, participant FP said, "I think webinars are good because you can do them at your desk. Generally, they are free or low cost depending on who's offering them." Additionally, participant LC indicated that webinars and CPEs are approximately 2 hours, and they teach a lot of information. Participant JF also stated that there are CPEs and webinars that directly address problems that NFPs encounter. Although there are few regarding fraud in NFPs, "a lot of those nonprofit-focused sessions are really about designing controls for organizations that cannot properly segregate all those processes."

Four participants had never taken CPEs or webinars. Of these individuals, $75 \%$ showed an interest in obtaining information regarding finding CPEs and webinars to benefit their fraud preparation. One participant explained that their organization has a specific online library with webinars on a variety of applicable topics. However, the participant stated that the system offers no webinars on the topic of fraud prevention, detection, or management and that learning those topics would be beneficial to her and others. This minor theme enabled the researchers to further support the idea that CPEs and webinars teaching fraud preparation are beneficial for the working professional. Research proves that these self-directed forms of learning are increasing and offer individuals more convenience, efficiency, and flexibility in their learning (Curran, et al., 2019). Utilizing these tools will help accountants in NFPs better prepare themselves for potential fraud occurrences.

\section{Minor Theme 3}

The third minor theme, "Who should receive fraud training?" was addressed by $100 \%$ of participants as it was a specific question in the interview guide. When asked, $53 \%$ believed that everyone in the organization would benefit from some level of fraud-prevention training. The remaining $47 \%$ of participants believed that leadership and accounting staff should be the main recipients of fraud-prevention training; with emphasis on anyone who had access to checks, transactions, or financial data. The majority of participants believed the role was irrelevant and fraud is a company-wide issue. Participant KT stated that they had "seen fraud perpetrated at all levels of the organization, or tolerance of it even at various levels of the organization." Participant $\mathrm{CN}$ noted that "fraud detection and prevention is everybody's 
responsibility." Additionally, participant RG believed that fraud-prevention training should explain, "not only how to detect it, but what constitutes it. What the consequences could be."

This minor theme verifies that accountants need improved fraud prevention, detection, and management training. Only three participants $(20 \%)$ stated that their organization offered post-hire fraud-prevention training. Although most participants had received training of some kind, it was not common that the organization specifically provided the opportunities for them to learn those topics. Addressing the question of who should receive training made the participants think critically about their organizations and identify which roles involve the most fraud risk and whether or not employees need fraud-prevention training. Additionally, by showing participants the various forms of fraud-prevention training and preparation available, they might choose to improve their education on fraud topics and better prepare themselves for potential occurrences.

\section{Minor Theme 4}

The last minor theme was only discussed by two participants (13\%); "Building a community to learn from is helpful." Participant SE explained that there are NFP groups and professional organizations that help provide information to other NFP professionals about pertinent topics. Participant SE also indicated the importance of speaking with people who had experienced fraud and undergone the process of detection and management. Participant LC stated that attending conferences is beneficial to fraud preparation and education. Participant LC also stated that the State Accounting Association and the Pennsylvania Institute of Certified Public Accountants (PICPA) offer fraud-prevention training to accounting professionals. Joining a community, whether NFP focused or not, can improve professionals' knowledge on various topics. Learning about the groups and professional organizations that are established for NFPs can improve the training that individuals in financial positions receive and give them a contact to ask questions if something arises that they do not know how to manage adequately.

\section{SUMMARY OF RESULTS AND LIMITATIONS}

\section{Summary}

This study was designed to answer the research question: "What preparations have NFP accountants had that would equip them for fraud prevention, identification, and management if any?" The study discovered that the preparation NFP financial professionals had was varied. The majority $(73 \%)$ of the participants received their preparation through CPE. Although CPE courses can aid in teaching about how to prevent, detect, and manage fraud, the findings indicate a need for improved fraud-prevention training in the NFP sector. The opinions and experiences provided prove that, although NFP finance professionals value fraud-prevention training, it is often overlooked by employers. Through the findings, the research identified various fraud-prevention training tools and techniques that NFP employers can utilize to better prepare their staff. Additionally, results identified specific topics that were of most use for the participants involved. Topics including professional skepticism, cybercrime, fraud red flags, and tone at the top were of value to the participants. By following the recommendations of this study, implementing some of the tools and techniques, and addressing the main fraud topics, NFP employers, employees, and educators can improve fraud-prevention preparation and lower future fraud risk.

\section{Limitations}

This study has various limitations; the most prominent was the small sample size. However, Marshall, et al. (2013), explains that 11 to 20 interviews are an adequate number of interviewees for a multiple case study. The authors believe that data saturation was possible with a smaller sample size using a multiple case study design.

Additionally, limitations exist because of the sensitivity of the topic. Research identifies fraud as a sensitive topic (Groenitz, 2016). Because of the negative consequences of revealing occurrences of fraud in an organization, the number of willing participants was limited. Similarly, there was a limitation regarding the potential for participants to withhold information. Participants might be uncomfortable 
sharing certain information that could damage the reputation of a colleague or the company (Mealer \& Jones, 2014). To alleviate these limitations, all potential participants were informed of their anonymity and of the protection of their information, including interview responses. The interviews were conducted at a neutral location with a reserved room to protect privacy.

The final limitation existed because the researchers could only contact participants whose NFP organization had contact information available online. There was no way of contacting participants whose organizations did not provide contact information on websites including Google, Pennsylvania Association Nonprofit Organization (PANO), and NFP websites. Because of this, the research target group selection phase included some self-selection. To alleviate this, the principal investigator included purposive snowball sampling, encouraging recruited participants to pass the invitation on to other NFP professionals who fit the study criteria.

\section{SUGGESTIONS FOR FURTHER RESEARCH}

Although the data collected through this study was beneficial for NFPs inside and outside of the study location, gaps continue to persist within existing research concerning fraud in NFPs and how to properly train employees to prevent, detect, and manage it. Filling such gaps is vital to improving knowledge for practicing NFP professionals and lowering fraud risk. Recommendations for future research are:

- Explore opinions of auditors regarding how the organizations could better prevent fraud,

- Identify which academic institutions offer courses on fraud education and how their graduates perceive their preparation,

- Compare perceived preparation of accounting students who receive fraud education to those who do not,

- Conduct a study identifying the effectiveness of CPE on the ability of NFP financial staff to prevent, detect, and manage fraud,

- Conduct the same study in a different geographical location to identify any differences in results,

- Explore the experiences that NFP accounting and finance professionals who do not have a Bachelor's degree in accounting,

Researchers believe that expanding the study boundaries will reveal more information regarding how NFPs, and NFP professionals, can become better prepared for preventing, detecting, and managing fraud.

\section{CONCLUSION}

This study sought to develop fraud-prevention training theories to identify gaps in existing research using the exploratory design. This study furthers the research by reducing gaps in the literature related to NFP fraud-training, and how NFP professionals could be better prepared to prevent, detect, and manage asset misappropriation. NFP accountants and leaders will benefit from this research by learning effective means of fraud prevention, detection, and management. These tools will enable their organizations to meet their mission and reduce loss.

\section{Reduction of Gaps}

Unlike the for-profit sector, there is minimal research regarding fraud in the NFP sector due to their preference for managing it internally (Archambeault, et al., 2014; Harris et al., 2017). This study adds to the existing literature by providing an analysis of various NFP organizations' fraud prevention, detection, and management techniques, and how they reduce fraud risk and loss. The researcher sought the opinions and experiences NFP professionals had with the prevention, detection, and management training, and how effective it was. The opinion of effectiveness was based on how the training helped the participants prevent fraud, as well as to detect and manage fraud that occurred in their workplace. 


\section{Benefits for Accountants and Leaders}

Accountants and leaders in NFPs will benefit from this study's results by the education of effective fraud identification, prevention, and management tools. NFP organizations struggle to find qualified, longterm help, as many workers are volunteers (Carey, et al., 2013; Thornhill, et al., 2016). This research will enable leaders to better qualify themselves and employees on effective fraud prevention, detection, and management techniques. The study's results will help NFP organizations protect themselves from fraudsters by teaching them to recognize fraud risk, and how to change policies and procedures to lower risks. Additionally, it will provide useful tools and techniques for NFP owners to implement in their fraudprevention training to further lower fraud risk.

Fraud creates problems for NFP organizations including loss of donor support, loss of trust, and a stained reputation (Archambeault \& Webber, 2017). To combat these consequences, many NFP organizations choose not to report fraud (Bromley \& Orchard, 2015). Educating NFP professionals about effective fraud prevention and encouraging employees to play a participative role in fraud detection, could lower their risk (Bradley, 2015). Internal controls in NFPs are verifiably weak, this study will teach accountants and leaders to improve existing policies and procedures, and lower fraud risk (Archambeault \& Webber, 2017).

\section{ACKNOWLEDGMENT}

The authors are grateful to NFP professionals in South Central Pennsylvania for their collaboration and participation in this research project.

\section{REFERENCES}

Akkeren, J.V., \& Buckby, S. (2017). Perceptions on the causes of individual and fraudulent co-offending: Views of forensic accountants. Journal of Business Ethics, 146(2), 383-404. doi:10.1007/s10551015-2881-0

Al-Thuneibat, A., Al-Rehaily, A.S., \& Basodan, Y.A. (2015). The impact of internal control requirements on profitability of Saudi shareholding companies. International Journal of Commerce and Management, 25(2), 196-217. doi:10.1108/IJCOMA-04-2013-0033

Andon, P., Free, C., \& Scard, B. (2015). Pathways to accountant fraud: Australian evidence and analysis. Accounting Research Journal, 28(1), 10-44. doi:10.1108/ARJ-06-2014-0058

Archambeault, D.S., \& Webber, S. (2017). Fraud survival in nonprofit organizations: Empirical evidence. Nonprofit Management and Leadership, 29, 29-46. doi:10.1002/nml.21313

Archambeault, D.S., Webber, S., \& Greenlee, J. (2014). Fraud and corruption in U.S. nonprofit entities: A summary of press reports 2008-2011. Nonprofit and Voluntary Sector Quarterly, 44, 1194-1224. doi:10.1177/0899764014555987

Association of Certified Fraud Examiners. (2018). Report to the nations 2018 global study on occupational fraud and abuse. Retrieved from https://s3-us-west2.amazonaws.com/acfepublic/2018-report-to-the-nations.pdf

Azzaro, A.G. (2018). Designing a framework for maintaining good moral character when providing accounting services to the legal cannabis industry (Unpublished doctoral dissertation). Liberty University, Lynchburg, VA.

Bik, O., \& Hooghiemstra, R. (2018). Cultural differences in auditors' compliance with audit firm policy on fraud risk assessment procedures. Auditing: A Journal of Practice \& Theory, 37(4), 25-48. doi:10.2308/ajpt-51998

Bradley, J.M. (2015). Empowering employees to prevent fraud in nonprofit organizations. Cardozo Public Law, Policy and Ethics Journal, 13, 711-738. Retrieved from https://heinonline.org/HOL/P?h=hein.journals/cardplp13\&i=763 
Bromley, P., \& Orchard, C.D. (2015). Managed mortality: The rise of professional codes of conduct in the U.S. nonprofit sector. Nonprofit and Voluntary Sector Quarterly, 45(2), 351-374. doi:10.1177/0899764015584062

Burchett, T.S. (2017). Fighting the "fraud plague" in purchasing \& procurement. Petroleum Accounting and Financial Management Journal, 36(2), 72-79. Retrieved from https://cob.unt.edu/ipa/journal

Carey, P., Knechel, W.R., \& Tanewski, G. (2013). Costs and benefits of mandatory auditing of for-profit private and not-for-profit companies in Australia. Australian Accounting Review, 23(1), 43-53. Retrieved from https://onlinelibrary.wiley.com/journal/18352561

Chang, Y.T., Chen, H., Cheng, R.K., \& Chi, W. (2019). The impact of internal audit attributes on the effectiveness of internal control over operations and compliance. Journal of Contemporary Accounting \& Economics, 15(1), 1-19. doi:10.1016/j.jcae.2018.11.002

Creswell, J.W. (2014). Research design: Qualitative, quantitative, and mixed methods approaches. Los Angeles, CA: SAGE Publications, Inc.

Curran, V., Gustafson, D. L., Simmons, K., Lannon, H., Wang, C., Garmsiri, M., . . Wetsch, L. (2019) Adult learners' perceptions of self-directed learning and digital technology usage in continuing professional education: An update for the digital age. Journal of Adult and Continuing Education, 25(1), 74-93. Retrieved from https://doi.org/10.1177/1477971419827318

Daher, M., Carré, D., Jaramillo, A., Olivares, H., \& Tomicic, A. (2017). Experience and meaning in qualitative research: A conceptual review and a methodological device proposal. Forum: Qualitative Social Research, 18(3), 62-85. doi:10.17169/fqs-18.3.2696

Di Mauro, C., Fratocchi, L., Orzes, G., \& Sartor, M. (2018). Offshoring and backshoring: A multiple case study analysis. Journal of Purchasing and Supply Management, 24(2), 108-134. doi:10.1016/j.pursup.2017.07.003

Domanski, J. (2016). Risk categories and risk management processes in nonprofit organizations. Foundations of Management, 8(1), 227-242. doi:10.1515/fman-2016-0018

Fahy, P.J. (2013). Uses of published research: An exploratory study. International Review of Research in Open and Distance Learning, 14(1), 145-166. Retrieved from http://www.irrodl.org/index.php/irrodl

Gao, J., Greenberg, R., \& Wong-On-Wing, B. (2015). Whistleblowing intentions of lower-level employees: The effect of reporting channel, bystanders, and wrongdoer power status. Journal of Business Ethics, 126(1), 85-99. Retrieved from https://www.jstor.org/stable/24702306

Groenitz, H. (2016). Risk-optimal estimators for survey procedures with certain indirect questions. Mathematical Methods of Statistics, 25(2), 133-144. Retrieved from https://www.springer.com/statistics/journal/12004

Harris, E., Petrovits, C., \& Yetman, M.H. (2017). Why bad things happen to good organizations: The link between governance and asset diversion in public charities. Journal of Business Ethics, 146, 149166. doi:10.1007/s10551-015-2921-9

Hollow, M. (2014). Money, morals and motives: An exploratory study into why bank managers and employees commit fraud at work. Journal of Financial Crime, 21(2), 174-190. doi:10.1108/JFC02-2013-0010

Johansson, E., \& Carey, P. (2016). Detecting fraud: The role of the anonymous reporting channel. Journal of Business Ethics, 139(2), 391-409. doi:10.1007/s10551-015-2673-6

Jones, C. (2014). Stopping nonprofit fraud: Helping your clients understand the risks. Accounting Today, 14. Retrieved from http://www.accountingtoday.com/news/stopping-nonprofit-fraud

Kampkötter, P., Harbring, C., \& Sliwka, D. (2016). Job rotation and employee performance - Evidence from a longitudinal study in the financial services industry. The International Journal of Human Resource Management, 29(10), 1709-1735. doi:10.1080/09585192.2016.1209227

Kong, Y., Lartey, P.Y., Bah, F.B.M., \& Biswas, N.B. (2018). The value of public sector risk management: An empirical assessment of Ghana. Administrative Sciences, 8(3), 40-57. doi:10.3390/admsci8030040 
Kramer, B. (2015). Trust, but verify: Fraud in small businesses. Journal of Small Business and Enterprise Development, 22(1), 4-20. doi:10.1108/JSBED-08-2012-0097

Kramer, B., Seda, M., \& Bobashev, G. (2017). Current opinions on forensic accounting education. Accounting Research Journal, 30, 249-264. Retrieved from http://doi.org/10.1108/ARJ-06-20150082

Kummer, T-F., Singh, K., \& Best, P. (2015). The effectiveness of fraud detection instruments in not-forprofit organizations. Managerial Auditing Journal, 30, 435-455. doi:10.1108/MAJ-08-2014-1083

Le, T.T.H., \& Tran, M.D. (2018). The effect of internal control on asset misappropriation: The case of Vietnam. Business and Economic Horizons, 14(4), 941-953. doi:10.15208/beh.2018.64

Liu, X.K., Wright, A.M., \& Wu, Y.J. (2014). Managers' unethical fraudulent financial reporting: The effect of control strength and control framing. Journal of Business Ethics, 129(2), 295-310. doi:10.1007/s10551-014-2156-1

Maguire, K. (2017). Minimizing fraud in the nonprofit grant process: Part II. Internal Auditing, 32(1), 614. Retrieved from https://www.tax.thomsonreuters.com/CheckpointJournals

Maguire, K.A. (2014). Best practices for nonprofits' internal control self-assessment. Advances in Management and Applied Economics, 4(1), 41-87. Retrieved from https://econpapers.repec.org/article/sptadmaec/

Marshall, B., Cardon, P., Poddar, A., \& Fontenot, R. (2013). Does sample size matter in qualitative research?: A review of qualitative interviews in IS research. The Journal of Computer Information Systems, 54(1), 11-22. doi:10.1080/08874417.2013.11645667

McDonnell, D., \& Rutherford, A.C. (2018). The determinants of charity misconduct. Nonprofit and Voluntary Sector Quarterly, 47(1), 107-125. doi:10.1177/0899764017728367

McNee, M. (2015). Nonprofit pulse: A leadership survey from Marks Paneth. Marks Paneth Accountants \& Advisors. Retrieved from https://www.markspaneth.com/

McSwain, M.Y., Wukich, J.J., \& McSwain, D.N. (2015). A fall from grace. Internal Auditing, 30(2), 3640. Retrieved from https://www.tax.thomsonreuters.com/CheckpointJournals

Mealer, M., \& Jones, J. (2014). Methodological and ethical issues related to qualitative telephone interviews on sensitive topics. Nurse Researcher, 21(4), 32. doi:10.7748/nr2014.03.21.4.32.e1229

Mirinaviciene, S. (2014). Internal control and fraud prevention: Prior research analysis. Science and Studies of Accounting and Finance: Problems and Perspectives, 9(1), 173-179. doi:10.15544/ssaf.2014.19

Mohd-Nassir, M., Mohd-Sanusi, Z., \& Ghani, E.K. (2016). Effect of brainstorming and expertise on fraud risk assessment. International Journal of Economics and Financial Issues, 6(4S), 62-67. Retrieved from https://www.econjournals.com/index.php/ijefi

Nawawi, A., \& Salin, A.S.A.P. (2018a). Employee fraud and misconduct: Empirical evidence from a telecommunication company. Information and Computer Security, 26(1), 129-144. doi:10.1108/ICS-07-2017-0046

Noland, T.G., \& Metrejean, E. (2013). The importance of the control environment: Expense account fraud at blue grass airport. Journal of Business \& Economics Research, 11(2), 97. doi:10.19030/jber.v11i2.7622

Prabowo, H.Y. (2014). To be corrupt or not to be corrupt: Understanding the behavioral side of corruption in Indonesia. Journal of Money Laundering Control, 17(3), 306-326. doi:10.1108/JMLC-112013-0045

Prins, K., \& Bhuse, V. (2018). Forced vacation: A rouge switch detection technique. European Conference on Cyber Warfare and Security (pp. 390-399). Retrieved from https://www.academic-conferences.org/conferences/eccws/

Reurink, A. (2018). Financial fraud: A literature review. Journal of Economic Surveys, 32(5), 1292-1325. doi:10.1111/joes. 12294

Rothschild, J. (2013). The fate of whistleblowers in nonprofit organizations. Nonprofit and Voluntary Sector Quarterly, 42(5), 886-901. doi:10.1177/0899764012472400

Rubino, M., Vitolla, F., \& Garzoni, A. (2017). How IT controls improve the control environment. Management Research Review, 40(2), 218-234. doi:10.1108/MRR-04-2016-0093

54 Journal of Leadership Accountability and Ethics Vol. 18(2) 2021 
Sahloul, M.M., Self, S.W., \& Simmons, M.M. (2019). Perceptions about accounting education related to occupational fraud: Review and analysis. International Journal of Business Research and Information Technology, 6(1), 30-49.

Scheetz, A.M., \& Wilson, A.B. (2019). Are not-for-profit employees more willing (or likely) to be whistleblowers? Journal of Public Budgeting, Accounting \& Financial Management, 31(1), 2-25 doi:10.1108/JPBAFM-06-2018-0054

Scholz, R., \& Tietje, O. (2002). Embedded case study methods. Thousand Oaks, CA: SAGE Publications

Self, S., Fudge, T., Sullivan, G., \& Harrington, T. (2016) Business acquisition: A case study with various accounting frauds. International Journal of Business, Accounting, \& Finance, 10(2).

Self, S., Machuca, A., \& Lockwood R. (2014). Differences in the performance on the certified public accountant exam of graduates from minority and non-minority institutions. International Journal of Education Research, 9(1).

Self, S., Weaver, D., Proctor, J., \& Hicks, M. (2013). Candidate performance on the certified public accountant exam: Empirical analysis. International Journal of Education Research, 8(1).

Singh, K., \& Best, P. (2016). Interactive visual analysis of anomalous accounts payable transactions in SAP enterprise systems. Managerial Auditing Journal, 31(1), 35-63. doi:10.1108/MAJ-10-20141117

Sow, A.N., Basiruddin, R., Mohammed, J., \& Rasid, S.Z.A. (2018). Fraud prevention in Malaysian small and medium enterprises (SMEs). Journal of Financial Crime, 25(2), 499-517. doi:10.1108/JFC05-2017-0049

Suh, J.B., Nicolaides, R., \& Trafford, R. (2019). The effects of reducing opportunity and fraud risk factors on the occurrence of occupational fraud in financial institutions. International Journal of Law, Crime and Justice, 56, 79-88. Retrieved from https://doi.org/10.1016/j.ijlcj.2019.01.002

Thornhill, R., Troy, C.J., \& Domino, M.A. (2016). Passing the plate: A survey of internal controls in local churches. The Journal of Theoretical Accounting Research, 12(1), 25-53. Retrieved from http://jtar.org/

Trompeter, G.M., Carpenter, T.D., Desai, N., Jones, K.L., \& Riley, R.A., Jr. (2013). A synthesis of fraudrelated research. Auditing: A Journal of Practice \& Theory, 32(1), 287-321. doi:10.2308/ajpt50360

Vitan, D., \& Mihălţan, D.C. (2015). Aspects regarding internal audit planning in the nonprofit organizations. Annals of the Constantin Brâncuşi University From Târgu Jiu: Economy Series, I(2), 366-371. Retrieved from https://doaj.org/

Wang, I.Z., \& Fargher, N. (2017). The effects of tone at the top and coordination with external auditors on internal auditors' fraud risk assessments. Accounting \& Finance, 57(4), 1177-1202. doi:10.1111/acfi.12191

Yin, R.K. (2009). Case study research: Design and method. Thousand Oaks, CA: SAGE Publications. 